\title{
The Importance of Music to Anders Behring Breivik Joe Stroud*
}

\begin{abstract}
This article considers the significance of popular music to the Norwegian terrorist Anders Behring Breivik, particularly the people he names in his manifesto: Helene Bøksle, Clint Mansell and Saga. Breivik saw these musicians, operating outwith the mainstream music industry, as conforming to his ideology, therefore playing a crucial role in making him feel part of a community during his period of isolation in preparation for his attack. This music also helped to motivate Breivik and maintain his morale. This article considers why this music in particular appealed to Breivik, and what he saw in it to confirm his ideology.
\end{abstract}

\section{Introduction}

On 22 July 2011, Anders Behring Breivik became one of the world's most notorious perpetrators of lone-wolf terrorism, killing eight people with a car-bomb in central Oslo, then moving to the island of Utøya, where he shot dead 69 attendees-mostly teenagers-at the summer camp of the Workers' Youth League (the youth wing of the Norwegian Labour party). While Breivik conducted these actions alone, (BBC, 2011) he was motivated by an ideology that had been acquired and influenced by a community of like-minded individuals connected through a variety of media. One medium of particular significance to Breivik was music. This article considers the various significances of music for Breivik, particularly in allowing him to visualise his attacks, in making him feel part of a community, and in being sufficiently malleable to be adapted to his ideology. More fundamentally, these functions fed into a broader role of music for Breivik, in motivating him and in maintaining his morale.

\section{Lone-wolf Terrorism and Community}

Lone-wolf terrorism is increasingly recognised as a rising phenomenon by scholars and governments. (Barnes, 2012) In the classification scheme proposed by Bates (2012), Breivik was a "chaos lone wolf"-in that his focus was on a single event. This is as opposed to a "career lone wolf" who aims to conduct a series of violent acts.

* Joe Stroud is a third year PhD Candidate in Musicology at the University of Edinburgh's Reid School of Music. His research, carried out under the supervision of Professor Simon Firth and Dr Elaine Kelly considers the role of popular music in extreme right wing movements, particularly in Europe. 
Breivik also conforms to one of Brym's criteria for individually executed terrorist attacks (albeit Brym's specific focus is on the characteristics of suicide bombers), (Brym, 2012) in that he was politically rather than religiously motivated (despite his stated target being Islam). (Brym Another of Brym's assertions, that "suicide bombers are not crazy" was supported by the Norwegian court judging Breivik to be sane. As this article argues, Breivik's interpretation of the music he cites is generally appropriate, and far from symptomatic of a deranged mind.

While Breivik conforms to these traits of lone-wolf terrorism, his designation as "lone-wolf" does not mean that he operated in total isolation. While Bates cites self-radicalization as a significant feature of lone-wolves, the process of this radicalization-through, for example, books writings, manifestos and music-is dependent on the existence of communities and channels of dissemination, and in particular on the ability of the lone-wolf to access these channels. In an article in a previous edition of this journal, Gabriel Weimann makes the point that lone-wolves "are not indeed so lonely: they are motivated, taught, recruited, incited or even trained by external sources; they display a degree of commitment to and identification with extremist movements; in other words, their solitary actions do not take place in a vacuum." (Weimann, 2012) Jonathan Rae similarly points out that ethno-nationalists "are intertwined into an interdependent close-knit community which requires high levels of trust and mutual commitment, far from the notions of psychosis or other pathological disorders." (Rae, 2012) Breivik was wary of declaring his political allegiance publicly, but music allowed him to imagine himself as part of a community, both political and aesthetic.

Perhaps the most conspicuous evidence of Breivik's outside influence can be seen in the composition of his manifesto, which Breivik himself admits is "60\% cut and paste," with the remainder original writings. (Siddique and Pidd, 2012) Breivik's plagiarism demonstrates the existence of a network in which he developed ideology and his reliance on the work of others. While Breivik's fondness for music is perhaps not so tangible as his dependence on the literature used in his manifesto (particularly the writings of Koenraad Elst and Robert Spencer), it still played a meaningful role in the preparation of his attacks. Music allowed Breivik to feel part of a community, even when his preparations required solitude. Through music, Breivik variously saw his ideology confirmed, enacted and espoused, even when his interpretation conflicted with the intention of the musicians. Music also afforded him the opportunity to visualise and romanticise his 
attacks, while maintaining his motivation and morale throughout the preparation process.

\section{Music in Everyday Life}

Breivik's writing on music (under the anglicised pseudonym Andrew Berwick) is mainly included in subsection 3.29 of his manifesto, "How to stay motivated for longer periods-perform a daily mental check." Here, he notes that the style of operation he is advocating requires isolation and self-sufficiency which can be psychologically challenging:

Becoming and maintaining the position as a self sufficient Justiciar Knight sleeper cell involves the capability to motivate/indoctrinate yourself over a prolonged period of time. Self-financed and self-indoctrinated single individual attack cells, is [sic] the backbone of the Knights Templar Europe. The importance of the ability for single cell commanders to be able to keep their spirits and morale up through self-indoctrination and motivation by using specific motivational techniques has been stressed on multiple occasions. (Breivik, 2011: 846)

Breivik advocates the use of ritual to prepare for "martyrdom," and to maintain morale and motivation:

I do a mental check almost every day through meditation and philosophising. I simulate/meditate while I go for a walk, playing my Ipod [sic] in my neighbourhood. This consists of a daily 40 minute walk while at the same time philosophising ideologically/performing self indoctrination and the mental simulation of the operation while listening to motivational and inspiring music. I simulate various future scenarios relating to resistance efforts, confrontations with police, future interrogation scenarios, future court appearances, future media interviews etc. or I philosophise about certain articles in the book. This daily mental exercise or ritual keeps me fully motivated and charges my batteries. And I'm sure it can work for other people as well. (Breivik, $2011: 845-6)$

Music clearly played a fundamental role in Breivik's ritualistic preparation, and was an important tool in maintaining his enthusiasm. Breivik goes on to cite three particular musicians as especially significant to him: Helene Bøksle, Clint Mansell and Saga. Each of these examples, while serving overlapping functions, demonstrate the various roles that music fulfilled for Breivik.

\section{Visualisation and Age of Conan}

The above quote suggests that visualisation was a significant part of Breivik's preparation process, and his use of music helped him 
to imagine himself in various roles and situations, notably carrying out the attack and the aftermath of it. Breivik's reference to himself as being a "Justiciar Knight Commander for Knights Templar Europe" and his use of a crusader-like cross on the manifesto cover unambiguously asserts his self-identification as a modern day knight, fighting against multiculturalism (which he sees as manifested particularly by Islam). Music is not the only non-literary medium which Breivik endorsed. Much has been made of his infatuation with computer games, particularly his claim that he used the first-person shooter game Call of Duty: Modern Warfare 2 (bought in February 2010) as a simulator in order to prepare for his attacks, (Breivik, 2011: 1418) stating in court that he used a "holographic aiming device" in the game to develop "target acquisition." (Pidd, 2012)

While this revelation received much attention, with some British MPs calling for a ban on such games, (Williams, 2012) Breivik himself was far more interested in fantasy games. He referred to the year between the summers of 2006 and 2007-during which he lived in his mother's home and played the online role-playing game World of Warcraft for up to 16 hours a day-as a "sabbatical," a reward for his years of hard work from 2002 and an indulgence before embarking on the preparation of his attacks. While World of Warcraft received the most attention, Breivik was also familiar with Age of Conan, another online role-playing game. Age of Conan was developed by a Norwegian company and is based on the 'Conan the Barbarian' character created by Robert E. Howard, with players taking on the roles of warriors and wizards in a fantasy setting. The soundtrack of Age of Conan, composed by Knut Avenstroup Haugen, incorporates various ethnic influences and themes to reflect the different races in the game. Despite the soundtrack's cosmopolitanism, it has a distinctly Norwegian flavour; along with Haugen, the Norwegian vocalist Helen Bøksle is prominent, and the lyrics on the soundtrack are in Old Norwegian, taken from the Poetic Edda.

While Haugen as composer is most responsible for the Age of Conan soundtrack, Breivik explicitly identifies it with Bøksle. The section in his manifesto in which Age of Conan music is referred to is headed "Motivational music tracks, artists: Helene Bøksle." Breivik refers to four tracks, including YouTube links to the songs: "The Dreaming Ere the World Crumbles," "Nighttime journey through the Eiglophian Mountains," "The Dreaming Anew - Memories of Cimmeria" and "The Awakening - Hyborian Adventures." Of these, the first three contain vocals by Bøksle, and are referred to by Breivik as "surpass[ing] almost 


\title{
The Importance of Music to Anders Behring Breivik
}

anything l've ever heard before." By contrast, the lack of vocals in "The Awakening" is noted specifically by Breivik, seen by him as "a decent track for maintaining a high morale during a limited battle confrontation." Bøksle's songs are also stated to be "worthy of playing during a martyrdom operation," and the following quote shows how Breivik imagines this music as a soundtrack for his own planned attack:

\begin{abstract}
Imagine the following; at the end of your mission, when you have completed your primary objectives - imagine fighting for your life against a pursuing pack of system protectors (or as I like to call them: armed defenders of the multiculturalist system, also referred to as the police). You try to avoid confrontation but they eventually manage to surround you. You hear this song as you push forward to annihilate one of their flanks, head shotting [sic] two of your foes in bloody fervor trying to survive. This angelic voice sings to you from the heavens, strengthening your resolve in a hopeless battle. Your last desperate thrust kills another two of your enemies. But it isn't enough as you are now completely surrounded; your time is now. This voice is all you hear as your light turns to darkness and you enter into the Kingdom of Heaven. This must surely be the most glorious way to claim the honour of martyrdom in battle. (Breivik, 2011:849)
\end{abstract}

It is clear that the use of music such as this allowed Breivik to envisage himself as a knight or crusader, fighting off the enemies of Europe. It is difficult to conceive of Breivik being able to visualise this scenario through any medium other than music, due to its indeterminate nature. It is also significant that Breivik-with his plan to use his iPod during his attack-was able to assume this music could indeed provide the soundtrack to his "martyrdom."

As well as his written manifesto, Breivik uploaded a video version to YouTube six hours before beginning his attack. This video compresses the arguments of his manifesto into a twelve-minute collection of images and quotes in four parts: "The Rise of Cultural Marxism," "Islamic Colonization," "Hope" and "New Beginning." As well as including images of Breivik armed and in uniform, the video calls on conservatives to embrace martyrdom, with Breivik apparently seeing himself as the spark that would rally a new generation of crusaders. While the content does not differ significantly from that of the written manifesto, the video affords Breivik the potential for soundtracking his material. He turns to Age of Conan to do so, using the three Bøksle tracks he cites in his manifesto, as well as "Akhet - Portal to Stygia" for the section "Islamic Colonization." The latter is clearly presented as a contrast to Bøksle, with a male singer and the use of the Arabic Hijaz scale. The contrast of the video is clear; Bøksle's music presents the familiarity of the West, while "Akhet" presents an unfamiliar and threatening 'other'. The use of music from Age of Conan is suggestive. 
It may seem strange that Breivik does not cite the game as significantmuch preferring World of Warcraft-but there is obvious relevance. First, the music itself is very well regarded and of high quality, with the composer winning awards for his score. Second, its Norwegian context chimes perfectly with Breivik's ideology; the use of Old Norwegian especially evokes a period which many on the extreme right see as a purer time. (Gardell, 2003) Third, the music is designed to be dramatic and increase adrenaline-a background for the game's combat situations-signalled most plainly by the prominent use of drums. Breivik declared that this music was appropriate to play during his "martyrdom operation," suggesting that he considered it appropriate accompaniment for his crusade.

\section{"Lux Aeterna": Battle Anthem}

Similarly drawn from a fantasy source, Breivik also refers to a work by Clint Mansell which was originally recorded as the soundtrack for the film Requiem for a Dream, though he identifies it with Lord of The Rings in his manifesto:

I love this work. Lux Aeterna means "eternal light" and it really is an appropriate title. I've listened to this track several hundred times and I never seem to get tired of it. The track is very inspiring and invokes a type of passionate rage within you. In Lord of the Rings - a good version of this track (Requiem for a Tower version which I think is the best) is performed during the most intense fighting of one of the central battles. Since it has worked for me, it is likely that it will work for you. An invigorating piece of art. (Breivik, 2011: 849)

In fact, "Requiem for a Tower" - an adaptation of Mansell's "Lux Aeterna" - was only used in a trailer for Lord of the Rings: The Two Towers, but this does not detract from the significance of Breivik's appropriation. In Lord of the Rings, the forces of good overcome overwhelming odds to defeat the forces of evil. Just as with the Age of Conan music, Breivik could use "Requiem for a Tower" to imagine himself in the role of hero, fighting the forces of darkness. It is possible that the contrast between the white-skinned forces of good and the dark-skinned forces of evil in these films added another level of compatibility with Breivik's ideology.

Breivik's conception of Mansell's work as battle music is shown by his reference to it later in his manifesto:

I will put my iPod on max volume as a tool to suppress fear if needed. I might just put Lux Aeterna by Clint Mansell on repeat as it is an incredibly powerful song. The combination of these factors (when added on top 
of intense training, simulation, superior armour and weaponry) basically turns you into an extremely focused and deadly force, a one-man-army. (Breivik, 2011: 1344)

His regard for the piece in general is also demonstrated by a recommendation to the future creators of an imagined European Federation, which Breivik foresees as providing the bulwark against Muslim and Marxist encroachment:

The formalisation of a new and powerful cultural conservative "European Federation" should have a new anthem. The anthem could be a vocal variation of: Lux Aeterna by Clint Mansell, and could be made available on [sic] all European languages. The vocal theme of the song should underline European unity against Jihad and the Islamic Caliphates in the past and our struggle against Marxism. (Breivik, 2011: 1205)

Breivik clearly imagines that the European Federation's main function will be to wage war against Islam, and the use of "Lux Aeterna" as an anthem reinforces the violent preoccupation of this vision.

Breivik's desire for an anthem, even if it is martial, reveals a desire to unite Europe against its enemies through music. Benedict Anderson, addressing the role of music in the imagining of communities, emphasises the uniting power of anthems:

No matter how banal the words and mediocre the tunes, there is in the experience a feeling of simultaneity. At precisely such moments, people wholly unknown to each other utter the same verses to the same melody. The image: unisonance. Singing ... provides occasions for unisonality, for the echoed physical realisation of the imagined community.... How selfless this unisonance feels! If we are aware that others are singing these songs precisely when and as we are, we have no idea who they may be, or even where, out of earshot, they are singing. Nothing connects us all but imagined sound. (Anderson, 1991: 145)

Breivik's vision of "Lux Aeterna" as a European anthem imagines the people of a continent united through song, although this utopian vision seems all the more fanciful when one considers the difficulties which have dogged the anthem of the European Union. (Fornäs, 2011)

\section{Saga: Ideological Confirmation and Aesthetic Satisfaction}

While Mansell and Bøksle represent the most mainstream of Breivik's musical inspirations-albeit in the relatively unusual realms of film and computer game soundtracks_-the musician given the most space in his manifesto is the Swedish singer known as Saga, a high-profile figure in the extreme-right music scene which promotes the ideology of white nationalism and supremacism. The extreme- 
right music scene originated in Britain in the late 1970s, with the punk band Skrewdriver being a notable part of this first wave of extremist music. During the 1980s and 1990s extreme-right musical culture established itself internationally, with particularly significant national scenes in Britain, Germany, Sweden and the United States. While it has a few associations with democratic groups, such as the Nationaldemokratische Partei Deutschlands in Germany, it also has a history of violent activism. This is particularly clear in the United States: Tom Metzger, founder of White Aryan Resistance (WAR) and an important figure in the establishment of extreme-right music in the USA, was a strong early advocate of lone-wolf terrorism (ADL); David Lane, a founding member of the terrorist group The Order, disseminated a number of writings from prison which included his views on music, while acting as a mentor figure to the notorious teen duo Prussian Blue (Quinn, 2007); and William Luther Pierce, leader of the National Alliance and owner of Resistance Records until his death (during which time it became a multi-million-dollar business), authored The Turner Diaries which depicts the revolutionary overthrow of the United States government and a race war to exterminate "impure" groups. The Turner Diaries is said to have inspired a number of terrorist groups and individuals, including The Order, David Copeland, and Timothy McVeigh. (SPLC, 2000)

Saga first came to prominence in the extreme-right scene with her covers of Skrewdriver songs released over the course of three albums. More recently, she released an album consisting of original material and covers of other canonic extreme-right songs. What distinguishes Saga, other than being a female in an overwhelmingly masculine realm, is the style of her music:

Saga is a courageous, Swedish, female nationalist-oriented musician who creates pop-music with patriotic texts. She is, as far as I know, the best and most talented patriotic musician in the English speaking world. And for those of you, like myself, who hates [sic] "metal", Saga is one of the few sources available that offers quality patriotic pop-music with brilliant texts. (Breivik, 2011: 847)

It seems likely that Breivik uses the term "metal" as a catch-all descriptor of the heavy guitar-based forms which characterise much extreme-right music. This suggests that Saga was particularly valuable to Breivik as, out of all the music which might be considered politically sympathetic to his ideology, hers was the most accessible given his aesthetic preferences. This point is worth emphasising; there is a vast amount of music-particularly from the extreme right-which Breivik could have used, but he had aesthetic preferences as well as 
ideological ones.

The importance of Saga to Breivik is demonstrated by the amount of space he devotes to her; not only does he write more on her than on Bøksle and Mansell combined, he also includes lyric transcriptions of his preferred songs. "Ode to a Dying People," a cover of a RaHoWa' song which Breivik cites as Saga's most popular work, makes clear that Saga's prime concern is with race.

It's all over except for the crying;

With a whimper instead of the roar of a lion;

The greatest race to ever walk the earth, walk the earth;

Dying a slow death with insane mirth;

The tomb has been prepared, our race betrayed, our race betrayed;

White man, fight the flight towards the grave;

[chorus]

If this is the way it ends, if this is the way my race ends;

If this is the way it ends, I can't bear to witness...

(Saga, "Ode to a Dying People")

Breivik himself tends to speak of multiculturalism and particularly Islam rather than race, but racial beliefs are evident in his reference to low average IQ in sub-Saharan Africa, and his statement that a stable and prosperous country must be ethnically homogenous. (Breivik, 2011) Just like many in the extreme-right music scene, Breivik turns accusations of racism back on to "the multiculturalists," claiming to be anti-racist, while also claiming that under multiculturalism whites have been major victims of other ethnic groups. (Breivik, 2011: 1357 \& 1389) Breivik was a huge fan of hip-hop in his youth, but now views it as essentially black and a destructive "ethnic industry," damaging to the fabric of European society. (Breivik, 2011: 1206-9)

However, there are differences between Saga's and Breivik's ideologies. Saga's grew from post-war neo-Nazism, while Breivik's prime concern is with Muslim occupation of Europe. Breivik, who consistently refers to himself as a "conservative," has a fairly low opinion of the ideology he refers to as National Socialist (NS), although he does see the potential for collaboration:

It will be extremely hard to cooperate with anyone who views our primary ally (the Jews/lsrael) as their primary enemy. Their Jew obsession and support to Islamic regimes will severely hinder any direct cooperation. They are blinded by their Jew hate to a degree where they fail to see the imminent threat to Europe represented by Islam.... However, we have certain things in common that shouldn't be underestimated. We share the same anti -EU, -UN and -immigration/multiculturalism (Muslim immigration

1 RaHowa is an abbreviation of the phrase "Racial Holy War." 
at least) sentiments and the goal of "preserving European traditions, culture etc" which is the primary reason why more and more ex-NS people are conforming and joining the new "European right". As a message to those hardcore NS's who are simply unable to compromise; Conform and join our armed struggle against the European cultural Marxists/multiculturalists (the enablers of the Islamisation of Europe), or continue to be sidelined and marginalised.... The cultural conservatives of Western Europe will seize power by 2080, if you want to be a part of this you will have no choice but to compromise. I would imagine that a continued Judeo Christian Europe would be considerably better than a European Caliphate even for the most hardcore NS. (Breivik, 2011: 1373-4)

Breivik therefore sees commonalities between his brand of conservatism and the ostensibly neo-Nazi extreme right, although he views Saga in particular as having sympathy with his ideology.

Marxist and multiculturalist character-assassins will claim that Saga is an evil, national-socialist monsterband from hell, due to her success. However, this characteristic couldn't be anywhere further from the truth. Although the environment surrounding Saga, the former NSF - National Sosialistisk Forening (a former Swedish Indigenous Rights Movement demonised as "evil Nazi monsters"), used to be self-proclaimed national socialists; it has become evident that most of them now has [sic] embraced a more national conservative ideological denomination of conservatism, very similar to that of Knights Templar Europe. Saga has created several pop-tracks with nationalist-oriented texts that will appeal to all conservatives, and especially revolutionary conservatives of all conservative ideological denominations. (Breivik, 2011: 847)

While Breivik's claiming of Saga for conservatism is somewhat tenuous, the ambiguous lyrical content of her songs allows for its appropriation by Breivik and his ideology.

For her part, Saga has disavowed any association between her music and terrorism, releasing the following statement in the wake of Breivik's attacks:

It has come to my attention that my music has been cited ... as going some way to inspiring one of the most vile and criminal acts in recent history. I cannot begin to describe how saddened I am to hear that and wanted to inform you all of my shock and utter horror at such an atrocity. My music is conceived to be a positive step towards celebrating our identity and bringing about positive cultural and political change. Like a great many artists and musicians, my music is designed to give hope to those who otherwise would have little. Change is brought about through political and cultural means by like-minds working together for a greater cause not brought about by warped loners acting out their murderous intentions. I have never sought to encourage or promote violence and I never shall. (Saga, 2011)

Yet, Saga's statement is undermined by her position as a leading 
figure in the extreme-right music scene. Extreme-right music tends to espouse lyrical themes of anti-Semitism, racism, anti-communism, white supremacism and white nationalism, often framing these themes in the language of conflict and struggle. Like Breivik, extreme-right music often has a preoccupation with myth and fantasy; it is common to find those involved in the extreme right making reference to historical figures like the crusaders or the Vikings and imagining themselves as modernday counterparts. For instance, the album artwork for No Remorse's This Time the World (Rebelles Européens, 1988) shows a skinhead as part of a continuum from the Viking age, through the Nazis, to the present day. Racial interpretations of fantasy stories, particularly those of J.R.R. Tolkien, place the extreme right as the representatives of good and light, fighting off the evil of other races. (Resistance, 2003) Clearly, these interpretations parallel Breivik's ideology and allow him to claim Saga's music for the conservative ideology of his Knights Templar Europe.

While Breivik obviously values the ideological confirmation he finds in Saga's music, he also makes strong claims for its ability to spur him on, at the same time making clear his personal admiration for Saga and her career:

Saga has the credibility to use the texts presented vocally as she has been a Swedish and European conservative resistance fighter for more than 10 years, working for the political and cultural interests of Sweden and the interests of all Swedes, Scandinavians and Europeans. Saga and similar patriotic heroes and heroines of Scandinavia, who unlike individuals like myself who has yet to come out of the "revolutionary conservative closet", has had to face political persecution and demonisation for years. Yet they continue their brave struggle to prevent the demographical and cultural genocide of the Scandinavian and European tribes. Instead of "physical" revolutionary or democratic resistance, she fights through her music by inspiring the best in us.

I discovered Sagas music relatively late, in 2008 , but have enjoyed it ever since. I have listened to many of the tracks several hundred times and I don't seem to get tired of them. I would HIGHLY recommend that all Justiciar Knights of Europe and other revolutionary conservatives use these tracks for self-motivating purposes. Don't just listen to the tracks but learn the texts as well. It has worked brilliantly for me and it will likely work just as well for you. ((Breivik, 2011: 847)

This passage reveals the extent to which Breivik found comfort in the music and the life-story of Saga, which suggests an importance beyond keeping him motivated. Saga's politics (and persecution) allowed Breivik to perceive her as a kindred spirit fighting for the same cause. Saga's popularity - albeit limited to the extreme-right music scene - 
Original Swedish lyrics to "Drömmarnas Stig":

Tvungen att vandra i pinande motvind; Dömd att leva i samhällets skugga; Ständigł förljugen av maktens språkrör;

Och föraktad av gemene man; Vore det inte simpelt att bara blunda;

Att avvika från våra drömmars stig?; Vore det inte en befrielse at† glömma; At† avsvära sig folksjälens plikt?;

Detta skall ses som en prövningarnas fas; Ödets verktyg att sålla bort veklingar;

Kampens styrka kommer av offervilja; Vår urgrund står på övertygelse;

Känner du dig då manad till strid?;

Låt dig själv aldrig tvivla på seger! also suggests a community of like-minded individuals united, as with his hopes for an anthem, through music.

\section{Conclusion}

It is no surprise that Breivik's favourite Saga song is "Drömmarnas Stig", a collaboration with musicians known as Midgård on Pro Patria III. The song is one of the few Saga songs in Swedish rather than English, thus appealing to Breivik's inclination towards Nordicism. It also highlights the difficulties faced by those who work for the "cause," and the ultimate victory that awaits them:

Forced to walk against the wind;

Doomed to live in the shadow;

Constantly lied to by the mouthpiece of power;

And despised by ordinary people. [chorus]

Wouldn't it be easier to just close our eyes;

To leave the path of our dreams?

Wouldn't it be a relief to forget;

To decline the duty of the folksoul?

This should be seen as a phase of tribulation;

The tool of destiny which will weed out the weak;

The strength of the cause comes from self-sacrifice;

Our foundation stands upon conviction;

Do you feel the need to fight?

Never let yourself doubt victory!

(Saga, "Drömmarnas Stig")

Even if Breivik felt unable to make contact with potential ideological comrades for fear of compromising himself, music such as this allowed him to perceive himself as part of a community who share his convictions, particularly that there is a fight to be fought, and victory to be achieved.

Perhaps the best evidence of Breivik's belief in community is in the manifesto itself; not only did he adopt the writings of others, but the very act of composing a manifesto and releasing it strongly suggests that he believed it would have an audience. While this audience may turn out to be mainly 
journalists and academics, Breivik did not write it as a confessional work. Rather, it documented his experiences in preparation for his attack and his advice for potential emulators, implying that Breivik believed that he would serve as a pioneer to be emulated, with successors who would have similar goals and tastes. Beyond this, music allowed Breivik to visualise himself in various roles in preparation for his attack. Through stimulating music such as Mansell's "Lux Aeterna" he sought to imagine the detail of his attack and work on suppressing his fear, while through Bøksle and Saga's work Breivik envisaged himself as a martyr and hero, sacrificing himself for his noble cause. It is significant that in these interpretations, Breivik can hardly be accused of misunderstanding the material: Mansell's and Bøksle's work was used to soundtrack media with violence and heroism as core components, while Saga's racial politics were easily adapted to Breivik's Islamophobia. So while Breivik's musical choices may be unexpected - and abhorrent to its creators - he could easily understand them as compatible with his ideology, and, by extension, it was possible for him to consider himself as part of a wider ideological community partly predicated upon shared musical taste.

While it is impossible to know whether the absence of this music would have made any significant difference to Breivik's attack, there can be little doubt that he valued it extremely highly. This is evident from the important part that music played in his motivational ritual, and the inspiration he drew from the musicians themselves, particularly Saga who, at least to Breivik, was charting a similar path in the face of persecution. The role of music in this case also conforms to ideas about terrorists not necessarily displaying overt psychological instability - in this case, Breivik's interpretation of the music - and lone-wolves not necessarily operating in isolation, with music providing a channel for Breivik to feel part of a community. Perhaps most significantly, Breivik considered music to be an element of violent acts themselves; not only did Breivik - as demonstrated in his writings - use music to visualise aspects of the attack, but he also clearly stated his intent to listen to "invigorating" music during the attack itself.

\section{Bibliography}

ADL. "Extremism in America - Tom Metzger: Ideology." Anti-Defamation League. http:// www.adl.org/learn/ext_us/tom-metzger/activityasp?LEARN_

Cat=Extremism\&LEARN_SubCat=Extremism_in_America \&xpicked=2\&item $=7$. Accessed January 15, 2013.

Anderson, Benedict. Imagined Communities: Reflections on the Origin and Spread of Nationalism (Revised Edition). London: Verso, 1991. 


\section{Journal of Terrorism Research Vol. 4 No. 1}

Barnes, Beau. "Confronting the One-Man Wolf Pack: Adapting Law Enforcement and Prosecution Responses to the Threat of Lone Wolf Terrorism." Boston University Law Review 92, no 5 (2012): 1613-62.

Bates, Rodger. "Dancing With Wolves: Today's Lone Wolf Terrorists." The Journal of Public and Professional Sociology 4, no 1 (2012). http://digitalcommons.kennesaw.edu/ jpps/vol4/iss 1/1. Accessed December 8, 2012.

BBC. "Norway attacks: 'Breivik acted alone'." BBC News, July 27, 201 1. http://www.bbc. co.uk/news/world-europe-14303363. Accessed December18, 2012.

Breivik, Anders Behring (as Andrew Berwick). 2083: A European Declaration of Independence. Self Published. 2011.

Brym, Robert. "The six lessons of suicide bombers." Contexts 6, no 4 (2007): 40-45.

Fornäs, Johann. Signifying Europe. Bristol: Intellect Books, 2011.

Gardell, Mattias. Gods of the Blood. Durham, NC: Duke University Press, 2003.

Pidd, Helen. "Anders Breivik 'trained' for shooting attacks by playing Call of Duty." The Guardian, April 19, 2012. http://www.guardian.co.uk/world/2012/apr/19/andersbreivik-call-of-duty. Accessed December 18, 2012.

Quinn, James. Nazi Pop Twins. Channel 4 (UK), 19 July, 2007.

Rae, Jonathan. "Will it Ever be Possible to Profile the Terrorist?" Journal of Terrorism Research 3, no 2 (2012). http://ojs.st-andrews.ac.uk/index.php/jtr/article/ view/405/431. Accessed January 15, 2012.

Resistance. "The Lord of the Rings: The Two Towers Movie Review." Resistance 21 (2003): 22.

Saga. 'Official Statement.' Saga Official, July 27, 201 1. http://thisissaga.com. Accessed December 182012.

Siddique, Haroon and Helen Pidd. "Anders Behring Breivik trial, day four." The Guardian, April19, 2012. http://www.guardian.co.uk/world/2012/apr/19/anders-behringbreivik-trial-live. Accessed December 18, 2012.

SPLC. "Once Again, The Turner Diaries Inspires Bloodshed." Intelligence Report 99 (2000). http://www.splcenter.org/get-informed/intelligence-report/browse-allissues/2000/summer/terrorism. Accessed November 26, 2012.

Weimann, Gabriel. "Lone Wolves in Cyberspace." Journal of Terrorism Research 3, no 2 (2012). Available at: http://ojs.st-andrews.ac.uk/index.php/jtr/article/ view/405/431. Accessed November 19, 2012.

Williams, Christopher. "MPs call for violent video game ban after Breivik claims that he 'trained' on Call of Duty: Modern Warfare." The Telegraph, May 17, 2012. http:// www.telegraph.co.uk/technology/video-games/9272774/MPs-call-for-violentvideo-game-ban-after-Breivik-claims-that-he-trained-on-Call-of-Duty-ModernWarfare.html. Accessed 18 December 2012. 